\title{
THE EFFECTS OF PRESENTATION METHOD AND LEARNING SKILL TOWARD ENGLISH ABILITIES FOR ELEVENTH GRADE STUDENTS AT SENIOR HIGH SCHOOLS IN EAST LAMPUNG
}

\author{
Pudjiono Sukoco \\ STKIP Kumala Lampung, Metro \\ Email: pudjionosukoco@gmail.com
}

\begin{abstract}
Learning activities is an educational process which has various ways and can give the impacts of student's learning English abilities. In fact most students find some difficulties specially in mastering English lesson at school. The different views about learning in educational process are met in the kind of initial conclusion that education is a process of preparing the young generation learning to live out and fulfill their destiny more effectively and efficiently. Some of the ways to make students are able to master an English lesson is by presentation method and students learning skill. The research has the following objectives: to determine the effects of presentation method on student abilities; to determine the influences of students' learning skill to students' abilities; to determine the effects of presentation method and student skill to students English abilities. The result obtained that the value of $t_{\text {count }}$ is greater than $t_{\text {table }}$ by calculating the $F_{\text {value }}$ of 7.976. Medium $F_{\text {table }}(0,05) \mathrm{N}=30$ is equal with 2.92. So $F_{\text {count }}>F_{\text {table }}$ or $7.976>2.92$. Therefore, H0 is rejected and $\mathrm{Ha}$ is accepted. It can be concluded that the method of presentation and student learning skill together give positive impacts toward student English ability. From the summary table is obtained the value of $\mathrm{R}_{\text {square }}$ of 0.371. This means that the two independent variables $\mathrm{X} 1$ and $\mathrm{X} 2$ together can influent of $37.1 \%$ and the balance of $62.9 \%$ affected by other factors that are not observed by the researcher.
\end{abstract}

Keywords: Presentation method, Learning skill, English ability

\section{INTRODUCTION}

Education is a system which designed by human for a specific reason. By education people will get various knowledge and technology. Everyone wants to achieve it to fulfill the life's need and to develop his welfare and ambition. That is why there are many schools are established to facilitate and provide the human willing. The students of Senior High School are at a level where they are mostly curious of something new and update. They obtain all by learning technology and information. But sometimes they find difficulty to know and master it because most are written in a foreign language especially English. In general they are lack of skill in speaking English fluently and correctly according to the international standard. In fact, the students have learnt and tried many 
ways in improving themselves to master English both spoken and written English in school even at courses. But they still get some hindrances and obstacles to gain it. If they practice and study English only with their friends at seat and rarely, they will not have a good mental to speak. Therefore, the teacher must use many methods in making them brave and good at using English. Teacher provides some choices in teaching students by seeking many information and technics. One of the methods is by using presentation Method.

The Presentation method is one of interesting learning to make them having well mental and fluent to speak and master English. But this needs a routine and interactive activity. This is expected to make students motivated, active, and creative. Each student has different characteristic, not everyone is able to understand the lesson quickly. This becomes a factor that can influent their learning English ability. Sometimes a teacher gives unclear explanation when teaching. So this can make students confused. By learning and presenting the English lesson, students are expected to develop his ability to understand and master English. In this context, education is not only a process of teaching which transfers knowledge but it also transforms values and characters that implicate to the personal and social life.

Besides, the learning skill also gives a big input in facilitating the English mastery. Developing student learning skill will help them to understand many kind of lessons. It will create a creativity and innovation of learning both in spoken and written English. By having this skill, students can improve their intelligence to manage time and method in achieving the quality of life. Learning skill gives another perspective that studying is not a form of routine activity in a formal institution but it is a process of continuing activity in life long education in different situation everywhere.

Jerold W. Apps (1978) stated that the underlying assumption of learning how to learn is that you, the learners, have the ability and the responsibility for planning much of your own learning in all aspects of life. It means that teaching skill enclaves the mastery and training in cognitive, affective, and psycho motoric. In brief, the learning skill is an acquired skill from individual through a continued and routine process optimally. The concept of learning how to learn is focused for each person to develop the learning style and the character.

By this research, the researcher expects that it will improve the English learning ability for the students of senior high school in east Lampung specially the students of eleventh grade. Most of them find difficulties in mastering both spoken and written English. Therefore, by using a presentation method and improving the learning skill, the students are expected to be able to master English lesson practically and theoritically. That is why the researcher formulates the case by giving a question of: Is there any effects of presentation method and learning skill together toward students English abilities? 


\section{LITERATURE REVIEW}

Method is from Greek "Methodos" means a way. The method is concerned to the way of understanding object. According to Sutikno (2014: 33-34). Method means a "way". Method is away or procedure used to achieve the certain goal. The knowledge of teaching method is very important and needed for teachers. This will determine the success of learning. A learning method that is able to motivate the students learning will improve the development individual and social student ability in facing the reality of life. The method is different from an approach. The approach focuses on the strategy and planning while the method focuses on the technics of learning. Gredler MB (1986:2).

In order to make learning process works properly and successfully, a teacher must determine an approach and method of learning before teaching. The right choice of learning and teaching method will influence the learning success. It is caused by the students are from different school, they will have different characters and ability. The environment also gives different impacts for students. A teacher must be smart in using the appropriate method of teaching and must use many methods to teach if he finds obstacle in using one method. He should be responsive and creative to find the right method if he gets failure. There are many methods designed and created by the experts in order to facilitate students in mastering knowledge in schools and environment. Because everyone is different, so the method should also be different.

\section{Presentation Method}

A presentation method is a method to expose idea, feeling, creativity in speaking, and establishing mental and applying theory into practice, Gredler MB (1986:2). Presentation is a presenting material in spoken language by the speaker by using organized thought and idea to explain material systematically. The speaker is freely expressing ideas according to the materials given. This needs a skill to speak and arranges good and interesting sentences in order to make audience understand and satisfied. Although there are many critics about presentation method, but this will develop student courage and mental to master English.

The presentation method can be effective to transfer knowledge and values to audience if the speakers are able to make the audience focus and comfortable to the lesson. This can motivate them to listen, pay attention, and apply for the materials. The adequate vocal power and interesting media will assist the successful activity of presentation. The most important thing is a style of communication and a little joke to make the presentation is not boring.

There are thre aspects that should be possessed to make an interesting presentation,

\section{Mind-set}

We must acknowledge the purpose of the presentation first before starting to speak in front of audience. The purpose will determine the direction of presentation and the style we use. Prepare an appropriate language to the audience we face. Arrange the material systematically. 


\section{Skill-set}

Skill has an important role to succeed the goal of presentation. It can be obtained by practicing, reviewing, and developing style of speaking. Students must be smart in responding audience to make appropriate words.

\section{Tool-set}

Tool-set is a media to assist the presentation becomes interesting and successfully. This will help audience easy to understand materials we present. It can be an audio-visual aid like LCD, pointer, in focus, power point, and so on. The skill-set is a main factor in the presentation. It can be gained by practicing and understanding audience using special technics and language style. These are the following techniques of successful presentation:

a. Read repeatedly and understand the materials as good as possible.

Before giving a presentation, read as much as possible the materials you are going to present. Take some references to get the additional knowledge. By understanding the materials, it will make you more ready and have a good mental.

\section{b. Learn your audience}

Understanding the audience will determine the success of giving presentation. We must know who your audience is. Then we try to use the appropriate language we use . The performance is the most important role in this situation. Arranging appropriate words will make the audience understand and satisfied. When you are at a seminar or workshop, dress yourselves in a good dress. Wear a tidy shirt with tie and suit. This will make you more confident. It also makes the audience feel honored and respected.

c. Be ready in facing the worst situation

When presenting a topic, suddenly the electric is off, so we must be ready to louder our voice. The presentation slide can't be used anymore. You must be ready to explain manually. You forgot the points which you are going to explain, so you must change the words in to a similar of it. And so on. Be relaxed as if you never get the worst situation. Continue the presentation without any aid and just feel comfortable to the condition.

d. Come earlier and well-prepared Prepare the tool-set in a good condition. Check everything concern to the presentation. Learn the materials before presenting the topics. We still have time to prepare while waiting audience.

e. Standing position and keep smiling

Stand in front of audience but do not cover the presentation screen or the white board. When explaining materials you are in the center of audience then return to the first position when writing something. Use gesture to strengthen some words. Smiling will make you comfortable and respect audience. 


\section{f. Use eyes contacts}

Stare at audience when speaking at glance and Make any interaction with them. They will feel be paid attention if we use eyes contacts to communicate and the also will listen our topics we present.

\section{g. Voice and Time.}

Louder the voice clearly to make the audience understand what we say. Avoid the repeatable words. Use the effective time in explaining materials. Do not waste the time for unimportant words.

\section{Learning Skill}

Learning skill is an acquired skill obtained by an individual through a continued training process and enclave cognitive, affective and psycho-motoric aspects. Everyone should develop his own learning characteristic and styles. Education is an external factor in the form of systematic engineering to improve learning skill quality and quantity. According to Goh Chock Tong P.M Singapore at the Singapore Expo (2001) stated that curriculum must emphasize on the creative and critical thinking ability to solve problems. It can grow if the students are discipline and use problem solving procedure and the communication skill to work together.

The development of learning skill needs some requirements according to the concept of "Being a human learner ". Life is for learning and use all self-potential to be worthy for all. Life for learning is more essential because it is useful for us. Knowles (1975) stated that the adequate learning skill will be able to support a learning process in mastering materials they learn. Everyone is directed to become an autonomous learner whom creates self-directed learning in many skills and expertise both in formal and non-formal institution. Long life education concept is a main guide of learning how to learn as in perspective as self-seen-as learner role of the essential learning component. This does not only focus on the cognitive aspect development but also the affective one.

Learning involves the changing process where something is gained and others are lost. In this context learning how to learn becomes a main focus is learning reorientation especially in context of self-perception and values. In this involves a learning perception transformation process, Mezirow (1978).

Senge, in Harefa (2000:139) stated that from learning, someone will 1) recreate his own personality, 2) do something new, 3) get in touch with the world deeper, 4) enlarge the life forming capacity process. In general learning skill can help people become better and more independent in learning. He will learn how to develop and apply for the personal management, inter-personal, cooperate skill to increase and improve the performance at school. Even it will assist student to create self-confidence and motivation to pursue the opportunity of success in the education or ambition.

Referring to the understanding of learning skill, we 
can conclude that learning skill enclave four main aspects:

a. Transformation of learning perception.

This can develop the basic skill such as reading, writing, listening, and speaking. This can train cognitive, affective, and psychomotoric for every student. So he is able to show the understanding of learning skill and strategy to get success.

b. The personal management skill.

The ability of applying for learning skill knowledge and his potential learning power can develop strategy to maximize learning success. It can improve the innovation in studying and achieving goal.

c. Interpersonal and Team work skill.

The ability in identifying and explaining knowledge and skill are needed to relate the interpersonal and team work. Besides that it also shows the appropriate ability in applying them in the learning environment.

d. Explorative opportunity

It can explore the document which is connected with the selfassessment, research, and career explorative in education field for the next future time.

The four elements become the characteristic of learning skill and is expected to undergo internalization process. This is very essential to develop in every steps of education. The reasons are :

a. Learning is a continued activity by each person since he was born till he dies and this becomes a fundamental foundation in learning that is : To live is to learn, it's not a task but a way to be in the world. Robinson (1979) In this context can be said that learning activities is a non-stop process to acquire many kind of skills in his all aspects of life.

b. Learning is a continued training. All the six senses are trained to be active in exploring knowledge. These become the instruments for learning because they are integrated in a set of learning skill to support the learning process in acquiring materials they learn. Knowles (1975), and Bergevin (1967)

c. The concept of long education is one of reference and main guide in the concept of how to learn where everyone is directed able to become autonomous learner in learning many kind of skills in formal and non-formal education.

There are three important factors in acquiring learning skill:

a. A positive mind-set and attitude.

We must have desire and passion toward studying and self-development. Learning is not only in the formal education but also in all aspects of life. The attitude of willing to listen, read, understand, and learn from others should be developed.

b. Accelerated Learning.

The unconsciousness mind is an extraordinary power if we are able to optimize the potential of thinking by reading and responding something as soon as possible. This will make our mind are used to developing ideas. 
c. Self-discipline and persistence.

Both of the elements will achieve the excellence of learning. Those will drive us in mastering every knowledge successfully. But they are not easy to do. It needs the selfcommitment and strong ambition. They are sometimes fluctuated according to someone mood.

\section{The Goal of learning Skill.}

The goal of learning skill is to be able to solve problems. Everyone is responsible to have ability in obtaining much knowledge from learning. To achieve the goal we must: 1) be able to know himself about his best talents. 2) be able to afford in actuating his ability and expressing himself by being himself. Harefa (2000:136). By knowing himself and his talent, he will be able to face challenge, difficulty, and hindrances in process of understanding himself. This process is based on transformative education concept. According to Darmaningtyas(1999:177), the cooperative and accommodating education will create a creative and free thinking process. This inspires to do analysis and establish the life mission. Meanwhile Rachman (2000:150) said that the actualization is needed to make someone becomes a human.

\section{Aspects of learning skill}

In the learning skill will appear other skills that enclave cognitive, affective, and psycho-motoric aspects. Education has a purpose to improve the quality of life technically through learning. The students will study continuously from various of unlimited learning sources. Students can acknowledge him and do something new even enlarge the personal capacity. They also will get a special skill that is called as life-skilled. As Gredler (1986:2) stated about the learning position in the process of human life. "Individual who has become skilled at self-directed learning are able to acquire a variety of new leisure-time and job-skills. He also has developed the capacity to endow their lives with life-long creativity."

\section{English language}

The language that is spoken in UK, US, and many other countries can be written in one English textbook "...The modern world is becoming smaller all the time..." Advances in transport and communications technology combined with the development of the world economy have resulted in people from different nations, cultures, languages and backgrounds now communicating, meeting and doing business with one another more than ever. One of the strong motivations for studying English for modern students is the fact that English is the language of business and the language of international communication. Very few businesses can escape from the need to some points in time deal with foreign colleagues, clients or customers. Business is international and if an organization wants to develop and grow it needs to harness the potential an international stage offers. Students now understand that the ability to speak English will be a great advantage in making their 
career and in international business communication. But speaking English is not enough to be able to crack foreign markets. The world's inhabitants come from many faiths, cultures, world views and experiences. This cultural diversity affects the business culture, especially when it comes to doing business across borders (whether political, religious, cultural or linguistic); it's obvious that successful communication requires not just excellent foreign language skills, but also cross-cultural understanding.

\section{Student Learning Ability}

Charles E. Johnson, (1974) in (Sanjaya Wina) said that Competence or ability as rational performance which satisfactorily meets the objectives for a desired condition. According to him the rational behavior is to achieve the goal required with the expected condition. So that the ability or competence is shown by the responsible performance in frame of achieving a goal we expect. This must be complicated task and it is not only done by one aspect. Someone should get in touch with experience of life both in formal and non-formal institution. $\mathrm{He}$ must possess the ability to respond the change in any aspects, and behave according to the norms and value in the society or any environment.

Ability or competency enclaves knowledge, understanding, skill, value, attitude, and interest. In the training-based competence concept said that the competence or ability is the combination of skill, knowledge, and attitude. The competence is used to assess the result standard. Besides that it is used to indicate the success in forming development system that can arrange student task. The competence or the ability standard is designed through curriculum according the students need. The students are expected to be able understand and apply for the knowledge by acquiring the combination aspects mentioned above. The implementation of knowledge, skill, and psychomotoric must be combined to achieve the goal of learning.

Cognitive ability contains understanding, application, analysis, observation, identification, investigation, exploration, connection, communication, inquiry, hypothesis, generalization, creativity, and problem solving. The effective ability enclaves the self-control, mood management, impulsive control, motivation, empathize. Meanwhile the psycho-motoric consists of socialization, personality, argumentation, presentation, and attitude. The ability which concerns with professional or academic specially cognitive is called by hard skill contributes $40 \%$ of success. While the affective and psychomotoric ability which are concerned with self-competence, socialization, and self-control are called soft skill contributes $60 \%$ of success.

\section{The frame of Thinking}

Based on the statements above, the effects of presentation method and learning skill are very important in developing learning ability for the students of eleventh grade at Senior high schools in East Lampung. The researcher finds that both variables 
will influent the students' competence. The figure below is shown as:

Figure 1.1

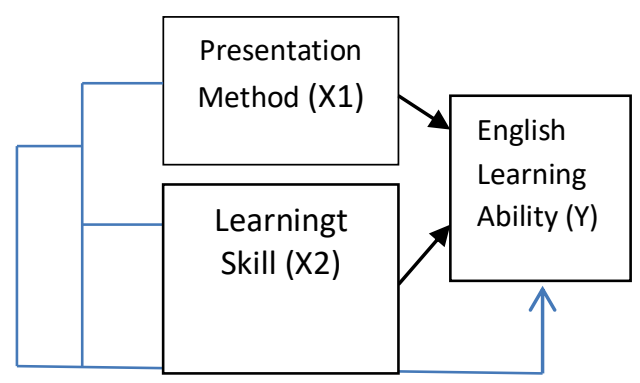

\section{RESEARCH METHOD}

The research is executed at senior high schools in East Lampung from January to March 2017. The design research is used to analyze research of the effects of presentation method and learning skill toward students learning ability for senior high schools at English subject is explanatory/confirmatory research because this explains the causal effects between the variables with the hypothesis assessment formulated.

\section{Hypothesis}

The hypothesis of the research, there is assumption that there are effects from both presentation method and learning skill toward English learning ability for the eleventh grade students of senior schools in east Lampung on English subject : To determine the effects of presentation method on student abilities, to determine the influences of students' learning skill to students' abilities. The research has the following objectives: To determine the effects of presentation method and student skill to students' English abilities.

\section{The Hypothesis Assessment}

The hypothesis assessment is done by using probability both in partial and simultaneous assessment. The result obtained that the value of $t_{\text {count }}$ is greater than $\mathrm{t}_{\text {table }}$ by calculating the $\mathrm{F}_{\text {value }}$ of 7.976. Medium $\mathrm{F}_{\text {table }}$ $(0,05) \quad \mathrm{N}=30$ is equal with 2.92. So $F_{\text {count }}>F_{\text {table }}$ or 7.976 $>$ 2.92. Therefore $\mathrm{H} 0$ is rejected and $\mathrm{Ha}$ is accepted. It can be concluded that the method of presentation and student learning skill together give positive impacts toward student English ability. From the summary table is obtained the value of $R_{\text {square }}$ of 0.371 .

This means that the two independent variables $\mathrm{X} 1$ and X2 together can influent of $37.1 \%$ and the balance of $62.9 \%$ affected by other factors that are not observed by the researcher.

\section{Simultaneous Assessment F (Anova) Assessment}

Table 1.2

\begin{tabular}{lrrrrr}
\multicolumn{5}{c}{ ANO $\mathbf{N}$} \\
\hline Model & $\begin{array}{c}\text { Sumof } \\
\text { Squqres }\end{array}$ & df & $\begin{array}{c}\text { Mean } \\
\text { squre }\end{array}$ & F & Sig \\
\hline 1. & 40.468 & 2 & 20.234 & 7.976 & 0,02 \\
Regres & 68.499 & 27 & 2.537 & & \\
sion & 108.967 & 29 & & & \\
Residu & & & & & \\
al & & & & & \\
Total & & & & & \\
\hline
\end{tabular}

a. Predictors

(Constant). Learning Skill (X2), Presentation Method (X1).

b. Dependent Variable Student learning Ability (Y)

The ANOVA shows the value of $F_{\text {count }}$ for both 
presentation method (X1)and learning skill(X2) are obtained the value of $F_{\text {count }}$ is 7.976 . While $F_{\text {table }}(\alpha 0.05) \mathrm{N}=30$ is 2.92. So that $F_{\text {count }}>F_{\text {table }}$ or $7.976>2.92$. This means that $\mathrm{H}_{0}$ is rejected $\mathrm{H}_{\mathrm{a}}$ is accepted. We can conclude that Presentation Method and Learning Skill simultaneously influence the students ability positively. This can be proven that The $F$ value is bigger than F table.

\section{Summary Model}

Table 1.3

Summary Model

\begin{tabular}{|l|c|r|c|c|}
\hline Model & $\mathrm{R}$ & $\begin{array}{c}\mathrm{R} \\
\text { square }\end{array}$ & $\begin{array}{c}\text { Adjusted } \\
\text { R squre }\end{array}$ & $\begin{array}{c}\text { Std. } \\
\text { Error } \\
\text { of the } \\
\text { estimat } \\
\mathrm{e}\end{array}$ \\
\hline 1 & .609 & 371 & .325 & $\begin{array}{r}1.5928 \\
0\end{array}$ \\
\hline
\end{tabular}

a. Predictors Learning Skill (X2), Presentation method (X1)

b. Dependent Variable : Student Ability (Y)

The table shows the value of $\mathrm{R}, \mathrm{R}^{2}$, adjusted $\mathrm{R}^{2}$ Std Error and Durbin Watson. Where the value of $R$ shows the combination from two independent variables $\mathrm{X} 1$ and $\mathrm{X} 2$ toward dependent variable $\mathrm{Y}$ is 0.609 . This indicates that both variables are significance $60.9 \%$. The rest is $39.10 \%$ are connected with other factors. The $\mathrm{R}$ value is 0.371 . This means that both independent variables $\mathrm{X} 1$ and $\mathrm{X} 2$ simultaneously influence $37.1 \%$ and the rest is $62.9 \%$ influences other factors.

\section{CONCLUSION}

After explaining the effects of presentation method (X1), Learning Skill (X2) toward Students English Ability (Y) at senior high school of eleventh grade students in East lampung The ANOVA shows the value of $F_{\text {count }}$ for both presentation method (X1)and learning skill(X2) are obtained the value of $F_{\text {count }}$ is 7.976. While $F_{\text {table }}(\alpha$ $0.05) \mathrm{N}=30$ is 2.92. So that $\mathrm{F}_{\text {count }}>\mathrm{F}_{\text {table }}$ or $7.976>2.92$. This means that $\mathrm{H}_{0}$ is rejected $\mathrm{H}_{\mathrm{a}}$ is accepted. We can conclude that Presentation Method and Learning Skill simultaneously influence the students ability positively. This can be proven that The $F$ value is bigger than F table

\section{REFERENCES}

Apps. Jarold. W (1979), Problems in Continuing Education. New York Mcgraw Hill Book Co.

Charles E. Johnson (1974:17), in Sanjaya Wijaya (2006:17), In Strategi Pembelajaran Jakarta. Kencana Prenada Media Group.

Darmaningtyas, (1999), Pendidikan Pada dan setelah Krisis. Yogyakarta. Pustaka Pelajar.

Gredler MB (1986:2), Learning and Instruction. Theory into 
Practice. NY: McMillan Publishing Company.

Goh Chok Tong (2001), Shaping Lives, Molding Nations PMs Keynote Address. By Prime Minister Goh Chok Tong at The Teachers Day Rally, at the Singapore Expo on Friday, $31^{\text {st }}$ August 2001.

Harefa, Andrias (2000), Menjadi manusia Pembelajar. Jakarta PT. Kompas Media Nusantara.

Knowless, Malcom (1975), Self Directed Learning (online), http://team6.metiri.wikispac esnet Accessed $21^{\text {st }}$ October 2010

Mezirow. J (1978), A Critical Theory of Adult Education XXXI (3)

Rachman, Budhi Munawar, (2000), Pendidikan, Praktek Politik dan pembebasan dalam menghapus Pendidikan Rakyat. Editor : Dadang S Anshori. Bandung Alqaprint jatinamgor

Robinson, HA, (1979), Teaching Reading and Study Strategies The Conten Areas Massachusetts. Allyn and bacon

Sutikno, (2014:33-34), Metode Pembelajaran, 2014 